Supporting Information for:

\title{
Stimuli-Induced Upgrade of Nuclease-Resistant DNA \\ Nano-Structure Composed of Single Molecular Beacon for Detecting Mutant Genes
}

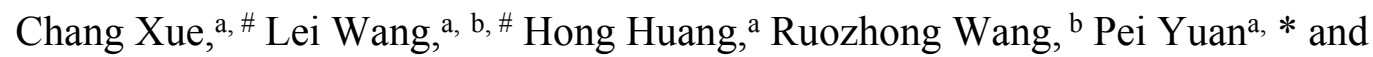
Zai-Sheng $\mathrm{Wu}^{\mathrm{a}, *}$

${ }^{a}$ College of Chemical Engineering, Cancer Metastasis Alert and Prevention Center, Fujian Provincial Key Laboratory of Cancer Metastasis Chemoprevention and Chemotherapy, Pharmaceutical Photocatalysis of State Key Laboratory of Photocatalysis on Energy and Environment, College of Chemistry, Fuzhou University, Fuzhou, 350108, China

${ }^{\mathrm{b}}$ Hunan Provincial Key Laboratory of Phytohormones and Growth Development, College of Bioscience and Biotechnology, Hunan Agricultural University, Changsha 410128, China

* Corresponding Author: Email: wuzaisheng@163.com (Z.S. Wu), Email: yuanpei@fzu.edu.cn (P. Yuan)

\# These authors contributed equally. 


\section{SA. Supporting experimental section.}

\section{SA.1. Stability evaluation of PMB.}

PMB $(1 \mu \mathrm{L}, 10 \mu \mathrm{M})$ and $2.5 \mu \mathrm{L}$ of $10 \times$ NEBuffer 2 were added into $21.5 \mu \mathrm{L}$ of $\mathrm{H}_{2} \mathrm{O}$. After mixing thoroughly, the mixture was heated at $90{ }^{\circ} \mathrm{C}$ for $5 \mathrm{~min}$ and then gradually cooled to room temperature, forming the PMB solution $(25 \mu \mathrm{L})$. FBS $(20$ $\mu \mathrm{L})$ was diluted with $\mathrm{H}_{2} \mathrm{O}(155 \mu \mathrm{L})$ and then added to the above solution, followed mixing thoroughly. The resulting mixture was immediately monitored at $\lambda_{\mathrm{em}}=520 \mathrm{~nm}$ for $1 \mathrm{~h}$.

\section{SA.2. Assay performance of PMB in serum.}

In FBS available commercially: PMB $(1 \mu \mathrm{L}, 10 \mu \mathrm{M})$ and $2.5 \mu \mathrm{L}$ of $10 \times$ NEBuffer 2 were added into $17.5 \mu \mathrm{L} \mathrm{H} \mathrm{H}_{2} \mathrm{O}$. After mixing thoroughly, the mixture was heated at 90 ${ }^{\circ} \mathrm{C}$ for $5 \mathrm{~min}$ and then gradually cooled to room temperature, forming the PMB solution. KRAS-M $(0.5 \mu \mathrm{L}, 10 \mu \mathrm{M}), \mathrm{KF}(0.5 \mu \mathrm{L}, 5 \mathrm{U} / \mu \mathrm{L})$, dNTPs $(0.5 \mu \mathrm{L})$, and FBS $(2.5 \mu \mathrm{L})$ were added and mixed thoroughly. The resulting FBS concentration is $10 \%$ $(\mathrm{V} / \mathrm{V})$. After incubating at $37{ }^{\circ} \mathrm{C}$ for $1 \mathrm{~h}$, the polymerization reaction was terminated by heating at $75{ }^{\circ} \mathrm{C}$ for $20 \mathrm{~min}$. The resulting solution was diluted with PBS to the final volume of $200 \mu \mathrm{L}$. After the fluorescence spectrum was collected, the fluorescence intensity was measured at $\lambda_{\mathrm{em}}=520 \mathrm{~nm}$.

In fresh serum: The blood was freshly sampled from mouse orbit, and then the serum were collected by centrifuging at $3000 \mathrm{rpm}$ for $5 \mathrm{~min}$. PMB $(10 \mu \mathrm{L}, 10 \mu \mathrm{M})$ and $2 \mu \mathrm{L}$ of $10 \times$ NEBuffer 2 were added into $8 \mu \mathrm{L}$ of $\mathrm{H}_{2} \mathrm{O}$. After mixing thoroughly, the mixture was heated at $90{ }^{\circ} \mathrm{C}$ for $5 \mathrm{~min}$ and then gradually cooled to room temperature, forming the PMB solution. The detection procedure was performed as follows: probe solution $(2 \mu \mathrm{L}), 10 \times \operatorname{NEBuffer} 2(2.5 \mu \mathrm{L})$, KRAS-M $(0.5 \mu \mathrm{L}, 10 \mu \mathrm{M})$, $\mathrm{KF}(0.5 \mu \mathrm{L}, 5 \mathrm{U} / \mu \mathrm{L})$ and dNTPs $(0.5 \mu \mathrm{L})$ were added to $19 \mu \mathrm{L}$ of the serum prepared above. The resulting serum concentration is $76 \%(\mathrm{~V} / \mathrm{V})$. After incubating at $37^{\circ} \mathrm{C}$ for $1 \mathrm{~h}$, the polymerization reaction was terminated by heating at $75^{\circ} \mathrm{C}$ for $20 \mathrm{~min}$. The resulting solution was diluted with PBS to the final volume of $200 \mu \mathrm{L}$. After the 
fluorescence spectrum was collected, the fluorescence intensity at $\lambda_{\text {em }}=520 \mathrm{~nm}$ was recorded.

\section{SA.3. Confocal microscopy imaging and atomic force microscopy analysis}

The samples were first prepared according to the same procedure as Figure 1. The experimental details are seen in the section of "Feasibility of DNS-MB for the detection of circulating tumor DNA".

For confocal microscopy: Freshly-prepared sample solution $(10 \mu \mathrm{L})$ was dripped on 22-mm cover glass. The bright field imaging was performed on a Leica SP8 laser scanning confocal micro-scope (Leica, Germany).

For atomic force microscopy: Freshly-prepared sample solution $(5 \mu \mathrm{L})$ was deposited onto fresh mica. After adsorption for 20 min, the mica was washed by $\mathrm{ddH}_{2} \mathrm{O}$ and dried with pure nitrogen. Then, AFM scanning was performed in ScanAsyst Mode on a MultiMode 8 atomic force microscope (Bruker, Germany). 
SB. Supporting tables.

Table S1. Oligonucleotide sequences designed in this study. ${ }^{\mathrm{I}}$

\begin{tabular}{c|l|l}
\hline \multicolumn{2}{l|}{ Function and name of probes } & \multicolumn{1}{|c}{ Sequence (5'-3') } \\
\hline & $\begin{array}{l}\text { Palindromic molecule } \\
\text { beacon (PMB) }\end{array}$ & TTTTTTTt/FAM/TT/GTCGCATTTGGAGCTGATGGCGT \\
AGTTTGCGACGt/BHQ1/C
\end{tabular}

IThe two boxed sequences in PMB represent the complementary fragments capable of forming a hairpin structure by intramolecular hybridization. The segment with gray background in PMB represents the palindromic fragment. The bases with lowercase letter in target and non-target species indicate the point mutations.

IIReprinted (Adapted or Reprinted in part) with permission from [ACS Appl. Mater. Interfaces 2019, 11, 18145-18152]. Copyright [2019] [American Chemical Society] 
Table S2. The detection of target and non-target DNAs via blind test.

\begin{tabular}{ccccc}
\hline Samples & RFI $^{\mathrm{I}}(\%)$ & RSD $^{\mathrm{II}}(\%)(\mathrm{n}=3)$ & Output & Marked \\
\hline 1 & 100 & 8.7 & KRAS-M & KRAS-M \\
2 & 73.2 & 3.7 & Non-target & KRAS-N \\
3 & 44.2 & 6.0 & Non-target & KRAS-G13S \\
4 & 59.1 & 3.5 & Non-target & KRAS-G13D \\
5 & 47.5 & 4.0 & Non-target & KRAS-G13C \\
6 & 33.6 & 4.3 & Non-target & KRAS-G13V \\
7 & 28.4 & 2.6 & Non-target & KRAS-G13R \\
\hline
\end{tabular}

${ }^{\mathrm{I}}$ RFI is the relative fluorescence signal that is calculated by the formula of $\left(\mathrm{F}-\mathrm{F}_{0}\right) /\left(\mathrm{F}_{\mathrm{t}}-\mathrm{F}_{0}\right) \times$ $100 \%$, where $\mathrm{F}, \mathrm{F}_{\mathrm{t}}$, and $\mathrm{F}_{0}$ represent the fluorescence intensity corresponding to non-target, target and Blank, respectively.

${ }^{\text {II }} \mathrm{RSD}$ represents relative standard deviation. 
Table S3. Recovery test for target DNA detection.

\begin{tabular}{ccccc}
\hline Samples & Targeted DNA added $(\mathrm{nM})$ & Found $(\mathrm{nM})$ & $\mathrm{RSD}^{\mathrm{I}}(\mathrm{n}=3)$ & Recovery $(\%)$ \\
\hline 1 & 10.0 & 10.2 & 0.53 & 101.7 \\
2 & 40.0 & 39.8 & 2.6 & 99.5 \\
3 & 60.0 & 61.3 & 1.7 & 102.2 \\
4 & 120.0 & 130.0 & 8.2 & 108.3 \\
\hline
\end{tabular}

${ }^{\mathrm{I}} \mathrm{RSD}$ represents relative standard deviation. 
Table S4. Comparative evaluation of DNS-MB probe and droplet digital PCR (ddPCR) for the detection of clinical specimens.

\begin{tabular}{ccc}
\hline Samples & $\begin{array}{c}\text { KRAS G12D concentration } \\
\text { detected by ddPCR }\left(\times 10^{-14} \mathrm{M}\right)^{\mathrm{I}}\end{array}$ & $\begin{array}{c}\text { KRAS G12D concentration } \\
\text { detected by DNS-MB }\left(\times 10^{-14}\right. \\
\mathrm{M}^{\mathrm{I}}\end{array}$ \\
\hline Patient \#1-PLA $^{\text {II }}$ & $1.43 \pm 0.07$ & $1.32 \pm 0.08$ \\
Patient \#2-CRC $^{\text {III }}$ & $1.20 \pm 0.04$ & $1.10 \pm 0.06$ \\
\hline
\end{tabular}

I The data are obtained by three repeated measurements.

II Patient \#1-PLA represents patient with primary lung adenocarcinoma (PLA).

III Patient \#1-CRC represents patient with sporadic colorectal cancer (CRC).

\section{Discussion:}

The polymerase chain reaction (PCR) has been recognized as a gold standard technique for nucleic acid detection ${ }^{1}$. Moreover, droplet digital PCR (ddPCR), the third-generation PCR method, ${ }^{2}$ has been developed as the advanced, reliable, and suitable techniques for detecting DNA mutation ${ }^{3,4}$ and become the standard method for the detection of ctDNA from serum samples ${ }^{5}$. Therefore, to further demonstrate the feasibility of DNS-MB probe for clinical applications, target DNAs in clinical specimens were separately analyzed by DNS-MB and droplet digital PCR (ddPCR). As shown in Table S4, the assay results obtained by DNS-MB system are in good agreement with the levels estimated by ddPCR (deviation $\leq 8.3 \%$ ). Additionally, compare with the considerable uncertainty $\left((1.16-8.86) \times 10^{-14} \mathrm{M}\right)$ of literature method for ctDNA detection in clinical specimens ${ }^{6}$, DNS-MB probe guarantee the accuracy of ctDNA analysis.

\section{Experimental procedure:}

For ddPCR-based detection: Blood samples were obtained from The First Affiliated Hospital of Wenzhou Medical University, China. DNAs were extracted with Rapid Blood Genomic DNA Isolation Kit (Sangon, Shanghai, China) according to the instructions, and the resulting solutions were stored at $-20^{\circ} \mathrm{C}$ before use. The total concentration of DNAs was quantified with a Quawell Q5000 micro-volume UV-Vis spectrophotometer (Quawell, USA). The extraction solutions (300 $\mu \mathrm{L}$ ) were divided into two groups, of which one was detected by droplet digital PCR (ddPCR), and another was detected by DNS-MB probe. The ddPCR assay was performed by Sangon Biological Engineering Technology \& Services Co., Ltd. (Shanghai, China). Briefly, QX200 droplet digital PCR system (Bio-Rad, USA) was used for the target detection. The volume of reaction solution was $20 \mu \mathrm{L}$ consisting of $10 \mu \mathrm{L}$ of ddPCR Supermix for Probes (No dUTP), 0.5 $\mu \mathrm{L}$ of $10 \mu \mathrm{M}$ probe, $1 \mu \mathrm{L}$ of template, $4.9 \mu \mathrm{L}$ of $\mathrm{H}_{2} \mathrm{O}$ and equal amount $(1.8 \mu \mathrm{L}, 10 \mu \mathrm{M})$ of forward primer and reverse primer. The reaction solution was loaded into the 8-well Droplet Generator (DG) Cartridge (Bio-Rad), and droplet generation oil (70 $\mu \mathrm{L})$ (Bio-Rad) was carefully loaded to generate the droplets. After generating droplets and transferring to a 96-well PCR plate, the amplification was performed according to the following steps: $95{ }^{\circ} \mathrm{C}$ for $10 \mathrm{~min}$; 40 cycles of $94{ }^{\circ} \mathrm{C}$ for $30 \mathrm{~s}$ and $60{ }^{\circ} \mathrm{C}$ for $60 \mathrm{~s}$; followed by $98{ }^{\circ} \mathrm{C}$ for $10 \mathrm{~min}$, and finally holding at $4{ }^{\circ} \mathrm{C}$. The result was read with QX200 Droplet Reader (Bio-Rad).

For DNS-MB probe-based detection: The extracted DNA sample was first concentrated to the volume of $5 \mu \mathrm{L}$ by heading at $40{ }^{\circ} \mathrm{C}$. Then, the target DNA in samples was measured according to the same procedure as described in Figure 2. The fluorescence signal was converted to the molar 
concentration of target DNA based on a standard linear calibration curve pre-established from the known concentrations of target DNA (Figure S5). 
Table S5. Comparison of DNS-MB with literature DNA probes for ctDNA detection. ${ }^{\mathrm{a}}$

\begin{tabular}{llllll}
\hline Material & LOD & Enzyme & $\begin{array}{l}\text { Reaction } \\
\text { time }\end{array}$ & $\begin{array}{l}\text { Detection } \\
\text { in serum }\end{array}$ & Ref. \\
\hline $\begin{array}{l}\text { DSNB + AgNFs + } \\
\text { DNA + RNA }\end{array}$ & $0.12 \mathrm{fM}$ & RNase HII & $22 \mathrm{~h}$ & yes & $(6)$ \\
\hline DNA & $0.32 \mathrm{pM}$ & $\begin{array}{l}\text { Phi29 DNA } \\
\text { polymerase + T4 } \\
\text { ligase }\end{array}$ & $20.5 \mathrm{~h}$ & yes & $(7)$ \\
\hline $\begin{array}{l}\text { Streptavidin + } \\
\text { modified magnetic } \\
\text { microparticles + DNA }\end{array}$ & $0.3161 \mathrm{pM}$ & $\begin{array}{l}\text { Exonuclease I }+ \\
\text { exonuclease III }\end{array}$ & $4 \mathrm{~h}$ & yes & $(8)$ \\
\hline $\begin{array}{l}\text { AuNPs + DNA + } \\
\text { gold electrode + Dox }\end{array}$ & $0.29 \mathrm{fM}$ & $\begin{array}{l}\text { Phi29 DNA } \\
\text { polymerase + T4 } \\
\text { ligase + Exonuclease } \\
\text { I + exonuclease III }\end{array}$ & $2.5 \mathrm{~h}$ & no & $(9)$ \\
\hline AuNPs + DNA & $1 \mathrm{fM}$ & FEN 1 & $4 \mathrm{~h}$ & no & $(10)$ \\
\hline Cholesterol + DNA & $50 \mathrm{fM}$ & DNA polymerase & $1 \mathrm{~h}$ & yes & Our method \\
\hline
\end{tabular}

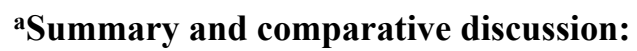

In Ref. 6, RNA site-embedded DNA probe was immobilized on silver nanoparticle films (AgNFs) for ctDNA detection with the help of RNase HII. Although the limit of detection (LOD) was 0.12 $\mathrm{fM}$, the preparation of DNA/AgNF complex is complicated, and the assay process takes as long as $22 \mathrm{~h}$. Moreover, the DNA/AgNF complex is stable only within 3 days, thereby limiting the detection time achieved $22 \mathrm{~h}$, which limited its application. In comparison, DNS-MB probe can be stored for a long time (e.g., one month and even a longer time). The target gene detection is accomplished within $1 \mathrm{~h}$ and only several mixing steps are involved.

In Ref. 7 and 8 , the assay sensitivity of the two methods is only subpicomolar level that is over 6-fold higher than DNS-MB probe. Moreover, compared with DNS-MB probe, the usage of two kinds of enzymes makes the assay cost-intensive and more complicated, and significantly longer assay time is required (ranging from $4-20 \mathrm{~h}$ ).

In Ref. 9, a satisfactory LOD is achieved by combing rolling circle amplification (RCA) with nanomaterial-based enrichment of redox indicator and sensitive electrochemical measurement. Nevertheless, the application of the method is hampered by complicated preparation process and high assay cost. For example, besides the preparation of sensing interface and requirement for four different enzymes, the ligation-based cyclization of circular template for RCA reaction needs to proceed overnight, and the construction of redox DOX@TDN-Au tag takes as long as 29 h. In contrast, DNS-MB system needs only one enzyme and only one probe, while the target assay is accomplished within only one hour.

In Ref. 10, flap endonuclease 1-assisted (FE-) DNA walker is a powerful probe for sensing ctDNAs, and the desirable LOD (1 fM) was achieved. However, besides the assay time of $4 \mathrm{~h}$, AuNP and different DNA probes are involved, and AuNP Functionalization takes as long as at least $48 \mathrm{~h}$. Moreover, the activity of enzyme is susceptible to the surface of AuNP according to the previous report ${ }^{11}$. In addition, the DNA walker is directly exposed to its surroundings and thus seems to be unsuitable for bioassay in a complex biological medium because of the inherent susceptibility of DNA strands to endogenous nuclease-mediated degradation ${ }^{12}$. Perhaps for this reason, the application of FE-DNA walker for the detection of ctDNA in serum is not evaluated. 
To meet the needs of real sample detection, we demonstrate nuclease-degradation resistant DNS-MB system composed of only one DNA probe. Unlike FE-DNA walker, DNS-MB does not exhibit a false positive signal even in freshly-sampled serum and is suitable for target gene detection in complex biological milieu. Moreover, a very simple assay process is employed, where only mixing steps are invoked and only $1 \mathrm{~h}$ is needed.

In conclusion, DNS-MB probe displays several advantages, such as high sensitivity, low assay cost, simple operation, rapid assay procedure, and low false-positive signal. 
Table S6. Abbreviations and corresponding definitions used in this study.

\begin{tabular}{|c|c|c|c|}
\hline Abbreviation & Definition & $\begin{array}{l}\text { Accepted } \\
\text { abbreviation }\end{array}$ & Definition \\
\hline PMB & Palindromic molecule beacon & SDA & $\begin{array}{l}\text { Strand displacement } \\
\text { amplification }\end{array}$ \\
\hline Chol-PMB & Cholesterol-modified PMB & ctDNA & Circulating tumor DNAs \\
\hline LPMB & Labeled-free PMB & PAGE & $\begin{array}{l}\text { Polyacrylamide gel } \\
\text { electrophoresis }\end{array}$ \\
\hline LChol-PMB & Label-free Chol-PMB & nPAGE & $\begin{array}{l}\text { Native polyacrylamide gel } \\
\text { electrophoresis }\end{array}$ \\
\hline e-Chol-PMB & Extended Chol-PMB & dsDNAs & double-stranded DNAs \\
\hline KRAS-M & Mutant KRAS G12D & NSCLC & Non-small-cell lung cancer \\
\hline KARS-N & Normal KRAS gene & PCR & Polymerase chain reaction \\
\hline Chol-DNA & Cholesterol-conjugated DNA & LOD & Limit of detection \\
\hline DMS & DNA micro-structure & dNTPs & $\begin{array}{l}\text { Deoxyribonucleoside } \\
\text { 5'-triphosphates }\end{array}$ \\
\hline DNS-MB & $\begin{array}{l}\text { Core/shell DNA } \\
\text { nanostructure composed of } \\
\text { single molecular beacon }\end{array}$ & FBS & Fetal bovine serum \\
\hline RFI & $\begin{array}{l}\text { Relative fluorescence } \\
\text { intensity }\end{array}$ & DLS & Dynamic light scattering \\
\hline KF & DNA polymerase & ddPCR & Droplet digital PCR \\
\hline $\mathrm{d}$ in Figure 1 & Diameter & PLA & Primary lung adenocarcinoma \\
\hline $\mathrm{F}$ & Fluorescence intensity & $\mathrm{CRC}$ & Sporadic colorectal cancer \\
\hline $\mathrm{C}$ & Concentration & & \\
\hline
\end{tabular}




\section{SC. Supporting Figures.}

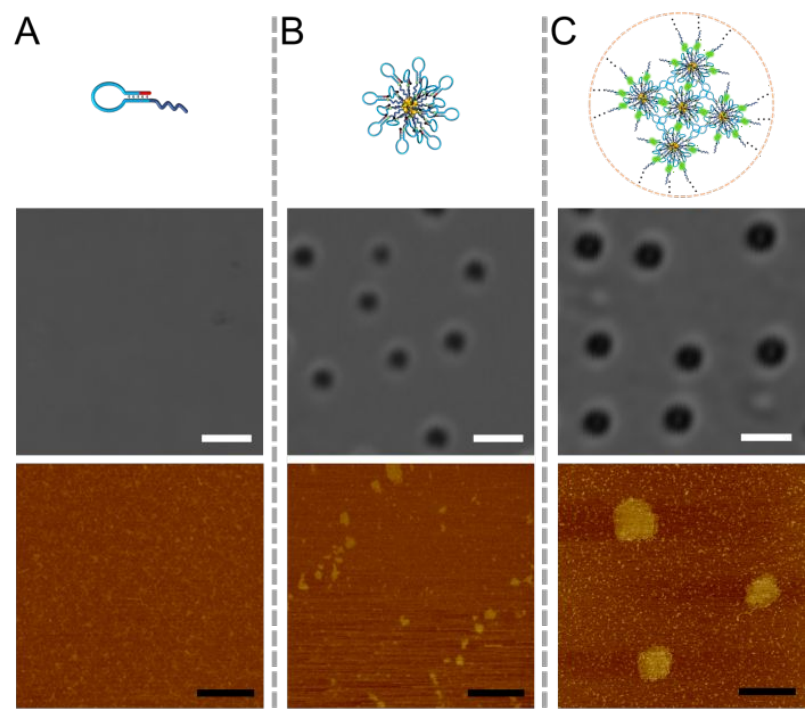

Figure S1. Microscopy analysis of PMB (A), DNS-MB (B) and DNA micro-structure (DMS) (C) by confocal microscopy (CM, upper panel) and atomic force microscopy (AFM, lower panel). DNS-MB is naturally assembled from Chol-PMB molecules in aqueous solution, while DMS is the finally-assembled products by the SDA-induced cross-linking between DNS-MBs. Scale bars in confocal microscopy $=2 \mu \mathrm{m}$, scale bars in $\mathrm{AFM}=0.6 \mu \mathrm{m}$.

\section{Discussion:}

For microscopy analysis of cholesterol-DNA-based nanostructures, according to literature report 13, confocal microscopy images of PMB, DNS-MB and DNA micro-structure (DMS) were taken. As shown the upper part of Figure S1, the size increases in the order of PMB $<$ DNS-MB $<$ DMS, which is consisted with the DLS results (Figure 1). Moreover, the morphologies of the three products have also been characterized by atomic force microscopy (AFM). The results are represented in the lower part of Figure S1. It can be seen that the size increases in the same order. Meanwhile, one can notice that there is difference in the size of DNA nanostructures between CM and AFM measurements. It is reasonable because the hydrodynamic size in solution is often much larger than the value measured in the air ${ }^{14}$. 


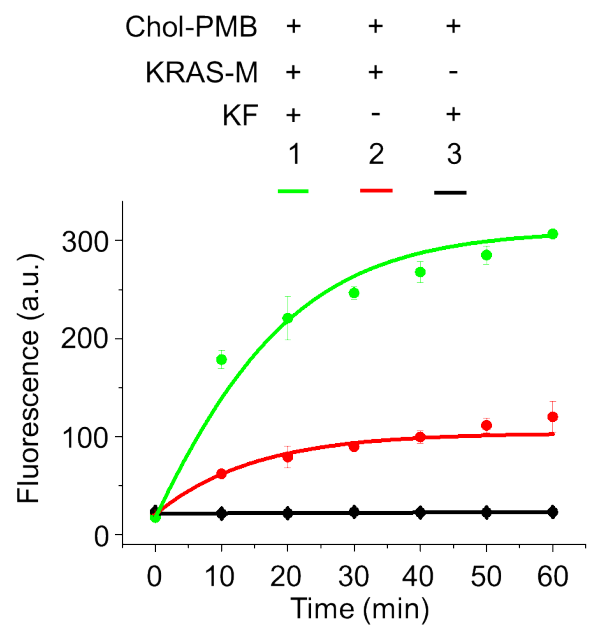

\begin{tabular}{|c|c|c|c|}
\hline NO. & $\begin{array}{c}\text { Kinetic rates } \\
(\mathbf{K r})\end{array}$ & $\begin{array}{c}\text { Concentration } \\
\text { of target }\end{array}$ & $\begin{array}{c}\text { Concentration } \\
\text { of KF }\end{array}$ \\
\hline 1 & 15.10 & $200 \mathrm{nM}$ & $0.1 \mathrm{U} / \mu \mathrm{L}$ \\
\hline 2 & 4.80 & $200 \mathrm{nM}$ & 0 \\
\hline 3 & 0.03 & 0 & $0.1 \mathrm{U} / \mu \mathrm{L}$ \\
\hline
\end{tabular}

$$
\begin{aligned}
& \mathrm{F}_{1}=295.9-251.6 \mathrm{EXP}(-0.06 \mathrm{t})(1) \rightarrow \mathrm{F}_{1}{ }^{\prime}=15.1 \mathrm{EXP}(-0.06 \mathrm{t}) \\
& \mathrm{Kr} 1=\mathrm{F}_{1(\mathrm{t}=0)}^{\prime}=15.1 \\
& \mathrm{~F}_{2}=115.8-95.6 \mathrm{EXP}(-0.05 \mathrm{t}) \quad(2) \rightarrow \mathrm{F}_{2}{ }^{\prime}=4.8 \mathrm{EXP}(-0.05 \mathrm{t}) \\
& \mathrm{Kr} 2=\mathrm{F}_{2(\mathrm{t}=0)}^{\prime}=4.80 \\
& \mathrm{~F}_{3}=22.9-0.85 \operatorname{EXP}(-0.04 \mathrm{t}) \quad\left(3 \rightarrow \mathrm{F}_{3}{ }^{\prime}=0.03 \operatorname{EXP}(-0.05 \mathrm{t})\right. \\
& \mathrm{Kr} 3=\mathrm{F}_{3(\mathrm{t}=0)}^{\prime}=0.03
\end{aligned}
$$

Figure S2. Kinetic curves of fluorescence change of Chol-PMB probe upon target stimuli and controls. (1) Chol-PMB + KRAS-M + KF; (2) Chol-PMB + KRAS-M; (3) Chol-PMB + KF, whose kinetic processes are fitted to the equations (1), (2) and (3), respectively. F1, F2 and F3 represent the fluorescence intensity and $t$ is the reaction time. The concentrations of Chol-PMB, p53 and $\mathrm{KF}$ are $400 \mathrm{nM}, 200 \mathrm{nM}$ and $0.1 \mathrm{U} / \mu \mathrm{L}$, respectively. 

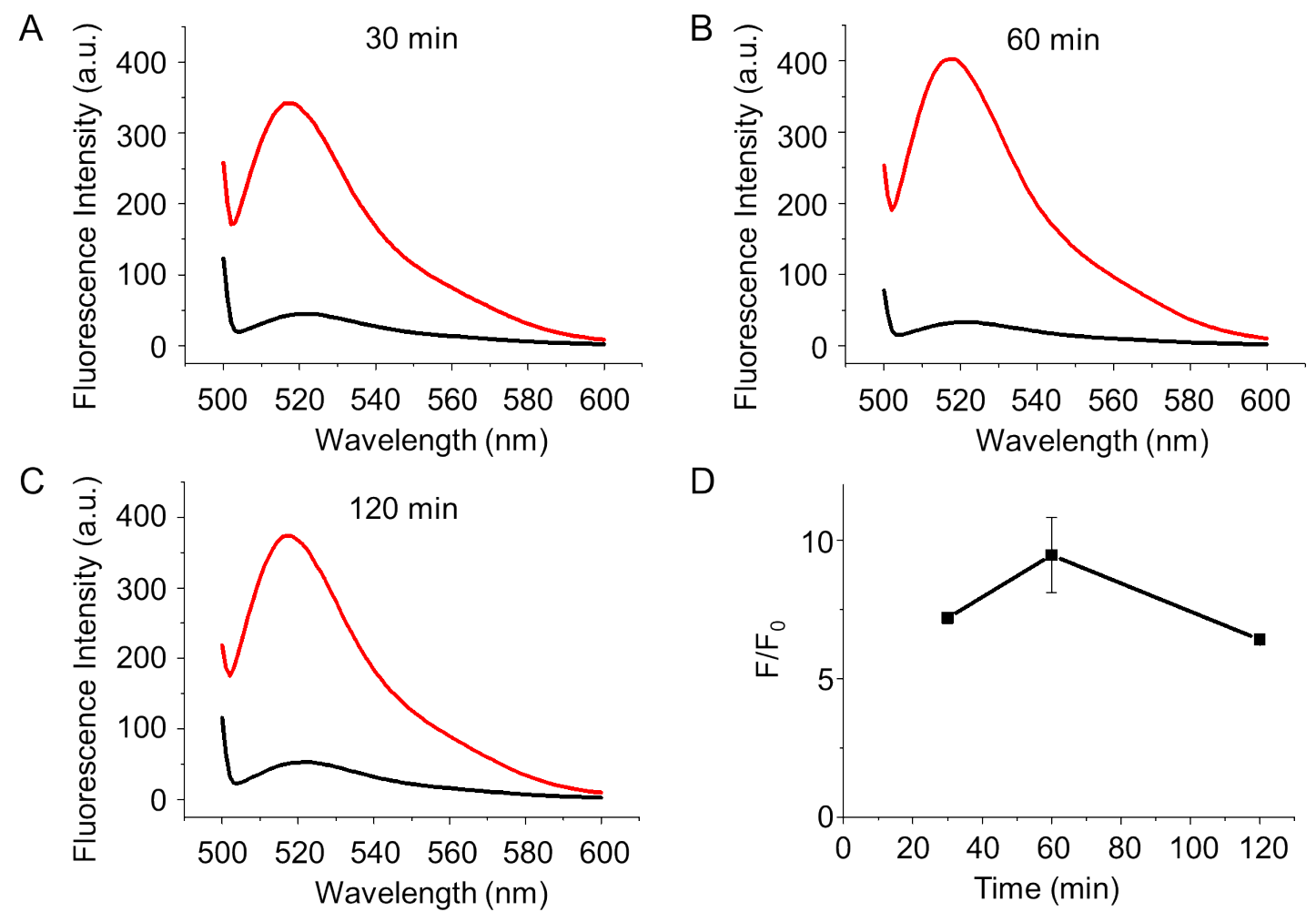

Figure S3. Optimization of reaction time. The fluorescence spectrum of DNS-MB probe in the presence (red line) and absence (black line) of KRAS-M incubated for $30 \mathrm{~min}$ (A), $60 \mathrm{~min}$ (B) and $120 \min (\mathrm{C})$. (D) The corresponding $\mathrm{F}$-to- $\mathrm{F}_{0}$ ratio values, where $\mathrm{F}$ and $\mathrm{F}_{0}$ represent the fluorescence intensity in the presence and absence of KRAS-M. The concentrations of Chol-PMB, KRAS-M and KF are $400 \mathrm{nM}, 200 \mathrm{nM}$ and $0.1 \mathrm{U} / \mu \mathrm{L}$, respectively. Error bars represent means \pm $\operatorname{SD}(n=3)$. 
A
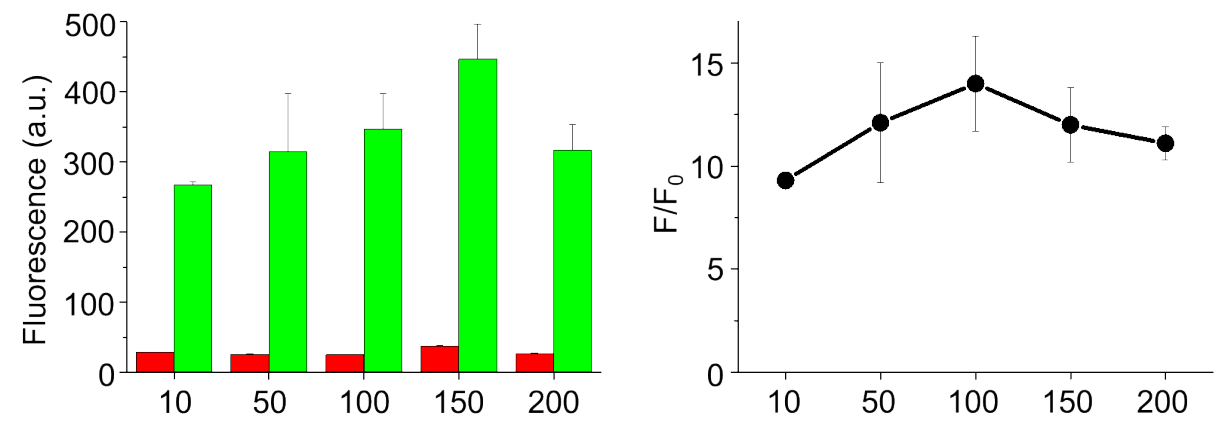

Concentration of $\mathrm{Mg}^{2+}(\mathrm{mM})$
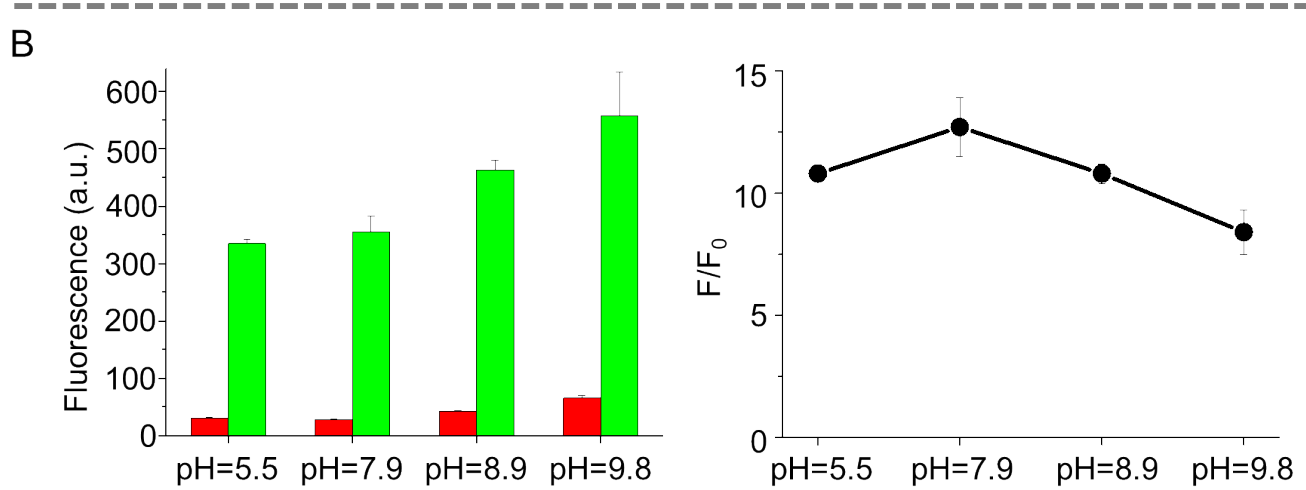

Figure S4. The dependence of fluorescence signal on $\mathrm{Mg}^{2+}$ concentration and $\mathrm{pH}$ value. (A) The fluorescence intensity of DNS-MB probe in the presence (green) and absence (red) of KRAS-M in NEBuffer 2 containing different concentrations of $\mathrm{Mg}^{2+}(10 \mathrm{mM}, 50 \mathrm{mM}, 100 \mathrm{mM}$, $150 \mathrm{mM}$, and $200 \mathrm{mM}$ ). (B) The fluorescence intensity of DNS-MB probe in the presence (green) and absence (red) of KRAS-M in NEBuffer 2 at different $\mathrm{pH}$ values ranging from 5.5 to 9.8. In the right panel show the corresponding $\mathrm{F}-\mathrm{t}_{0}-\mathrm{F}_{0}$ ratios, where $\mathrm{F}$ and $\mathrm{F}_{0}$ represent the fluorescence peak in the presence and absence of KRAS-M. The concentrations of Chol-PMB, KRAS-M and KF are $400 \mathrm{nM}, 200 \mathrm{nM}$ and $0.1 \mathrm{U} / \mu \mathrm{L}$, respectively. Error bars represent means $\pm \mathrm{SD}(\mathrm{n}=3)$.

\section{Discussion:}

As shown in Figure S4A, the fluorescence signal upon target gene gradually increases with the increment of $\mathrm{Mg}^{2+}$ concentration. After reaching the highest value at $150 \mathrm{mM} \mathrm{Mg}^{2+}$, the fluorescence signal decreases when further increasing the $\mathrm{Mg}^{2+}$ concentration. Meanwhile, there is a slight difference in the background fluorescence at different $\mathrm{Mg}^{2+}$ concentrations. The possible reason is that the high $\mathrm{Mg}^{2+}$ concentration favors the hybridization of target gene with DNS-MB, improving the fluorescence signal. However, much higher $\mathrm{Mg}^{2+}$ concentration makes the hairpin structure more stable and/or compromises the enzymatic activity of polymerase, hampering the signal transduction. The curve of F-to- $\mathrm{F}_{0}$ ratio shows that the optimal $\mathrm{Mg}^{2+}$ concentration for target gene detection is $100 \mathrm{mM}$. For the relationship between $\mathrm{pH}$ and fluorescence signal, as shown in Figure S4B, the highest signal-to-noise ratio ( $\mathrm{F}-$-to- $_{0}$ ratio) is achieved at $\mathrm{pH}$ 7.9. Presumably, the lower or higher $\mathrm{pH}$ is unfavorable for DNA hybridization and/or enzymatic polymerization. Thus, target gene detection is performed at $100 \mathrm{mM} \mathrm{Mg}^{2+}$ and $\mathrm{pH} 7.9$ 
A

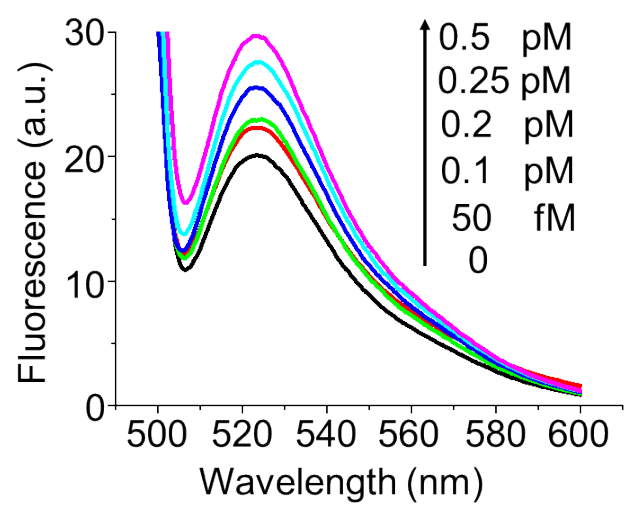

B

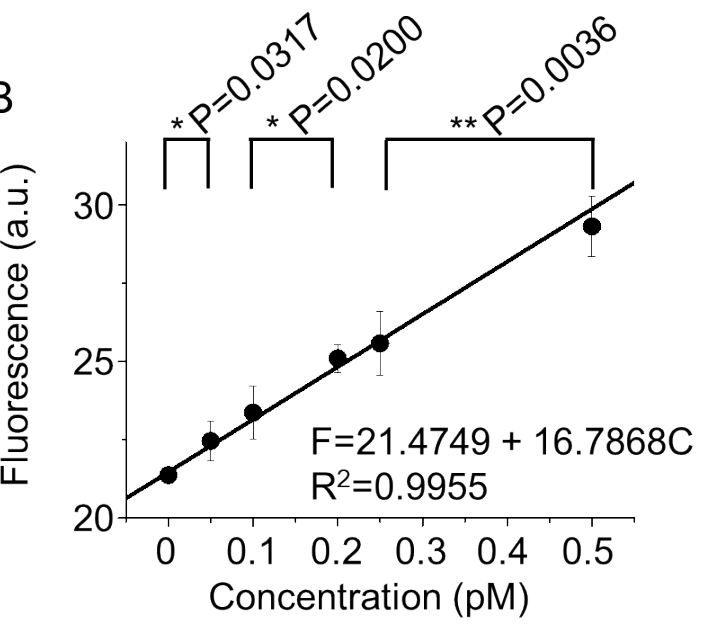

Figure S5. Quantitative detection of target DNA at low concentration by DNS-MB probe.

(A) Fluorescence spectra of DNS-MB upon the different concentrations of target DNA: 0, $50 \mathrm{fM}$, $0.1 \mathrm{pM}, 0.2 \mathrm{pM}, 0.25 \mathrm{pM}$, and $0.5 \mathrm{pM}$. (B) The calibration curve between fluorescence signal and target concentration in the low concentration range. The concentrations of Chol-PMB and KF were $400 \mathrm{nM}$ and $0.1 \mathrm{U} / \mu \mathrm{L}$, respectively. The incubation time for polymerization was $1 \mathrm{~h}$. Error bars represent means $\pm \mathrm{SD}(\mathrm{n}=4) .{ }^{*} \mathrm{P}<0.05,{ }^{* *} \mathrm{P}<0.01$ (two-tailed unpaired $\mathrm{t}$ test). 


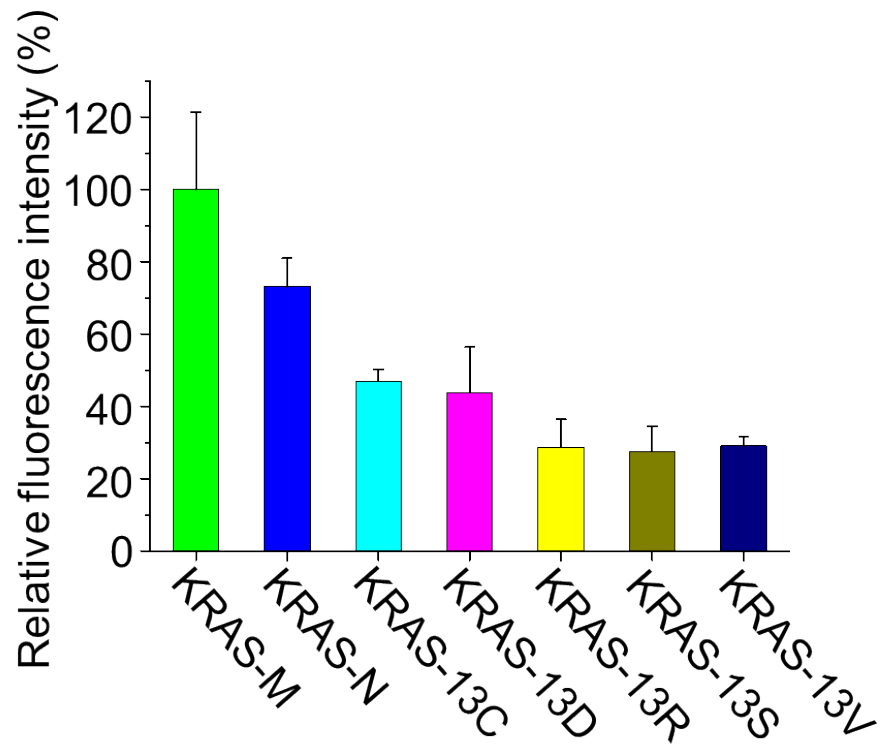

Figure S6. Assay specificity of DNS-MB probe towards KRAS-M. The relative fluorescence intensity (RFI) was calculated by the formula of $\left(\mathrm{F}-\mathrm{F}_{0}\right) /\left(\mathrm{F}_{\mathrm{t}}-\mathrm{F}_{0}\right) \times 100 \%$, where $\mathrm{F}, \mathrm{F}_{\mathrm{t}}$, and $\mathrm{F}_{0}$ represent the fluorescence intensity corresponding to non-target, target and Blank, respectively. The concentrations of Chol-PMB, target, non-target and $\mathrm{KF}$ are $400 \mathrm{nM}, 200 \mathrm{nM}, 200 \mathrm{nM}$ and 0.1 $\mathrm{U} / \mu \mathrm{L}$, respectively. Error bars represent means $\pm \mathrm{SD}(\mathrm{n}=3)$. 


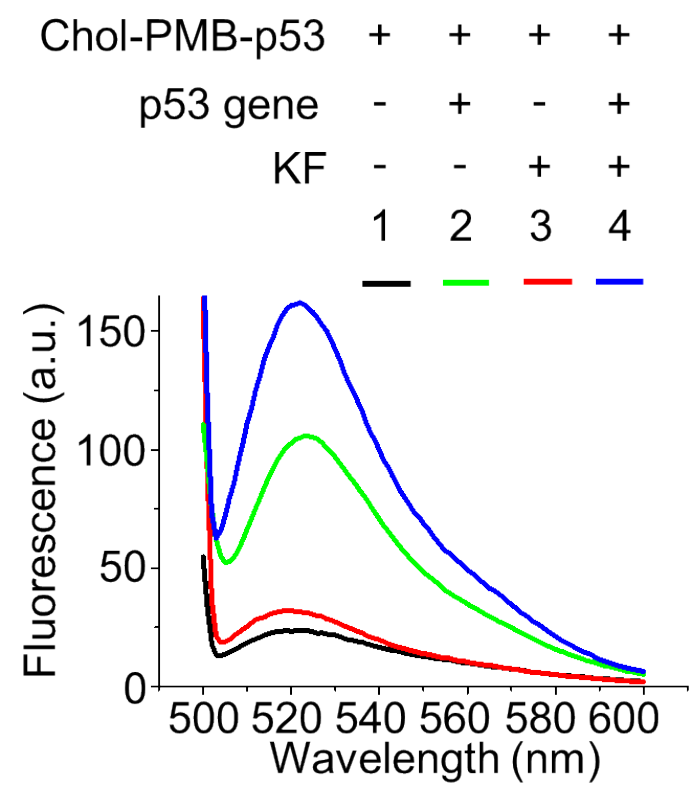

Figure S7. Feasibility of DNS-MB for p53 detection. Fluorescence spectra upon target gene and corresponding counterparts: (1) Chol-PMB-p53; (2) Chol-PMB-p53 + p53; (3) Chol-PMB-p53 +KF; (4) Chol-PMB-p53 + p53 + KF. The concentrations of Chol-PMB-p53, p53, and KF are 400 $\mathrm{nM}, 200 \mathrm{nM}$ and $0.1 \mathrm{U} / \mu \mathrm{L}$, respectively. 
A

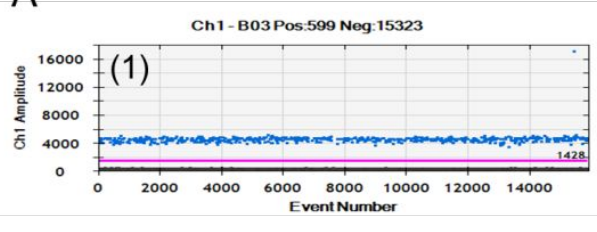

Ch1 - C03 Pos:494 Neg: 1413

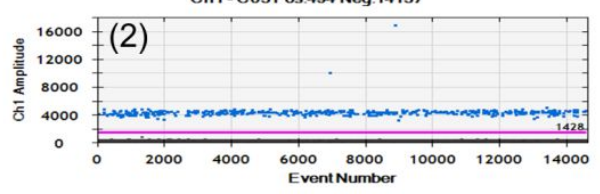

Ch1-D03Pos:570 Neg:15045

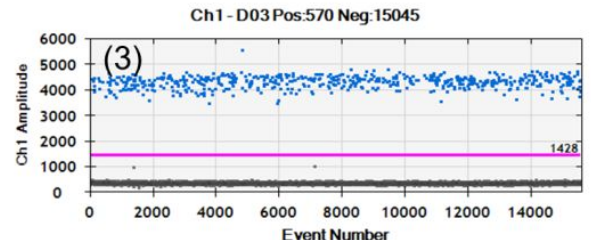

B

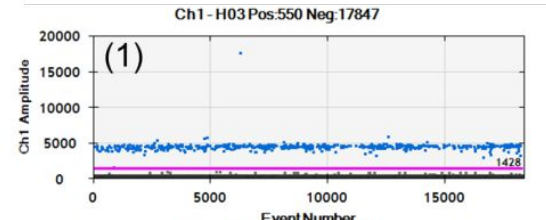

Event Number
Ch1-A04 Pos.522 Neg: 17474

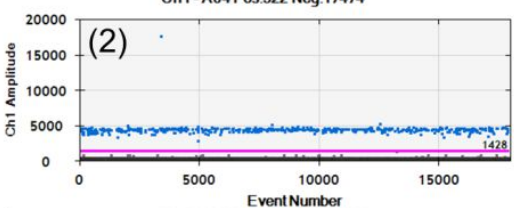

Event Number
Ch1 - B04 Pos.514 Neg:15803

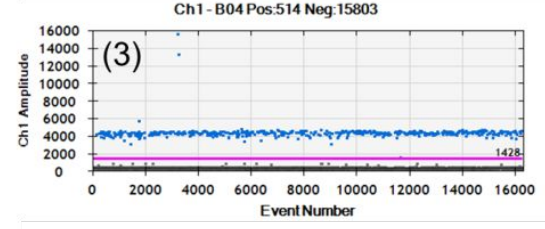

Figure S8. The 1D plots of droplet digital PCR (ddPCR)-based analysis of clinical specimens. (A) Patient with primary lung adenocarcinoma (PLA). (B) Patient with sporadic colorectal cancer (CRC). Blue dots represent the positive signal, while (1), (2), and (3) represent three independent measurements. The clinical specimens were obtained from The First Affiliated Hospital of Wenzhou Medical University, China. The ddPCR assay was performed by Sangon Biological Engineering Technology \& Services Co., Ltd. (Shanghai, China). 


\section{REFERENCES}

(1) Peeters, B.; Safdar, S.; Daems, D.; Goos, P.; Spasic, D.; Lammertyn, J., Solid-Phase PCR-Amplified DNAzyme Activity for Real-Time FO-SPR Detection of the MCR-2 Gene. Anal. Chem. 2020, 92, 15, 10783-10791. https://doi.org/10.1021/acs.analchem.0c02241.

(2) Szczerbal, I.; Nowacka-Woszuk, J.; Albarella, S.; Switonski, M., Technical note: Droplet digital PCR as a new molecular method for a simple and reliable diagnosis of freemartinism in cattle. J. Dairy Sci. 2019, 102, 10100-10104. https://doi.org/10.3168/jds.2019-17021.

(3) Hiemcke-Jiwa, L. S.; Minnema, M. C.; Radersma-van Loon, J. H.; Mehdi Jiwa, N.; Boer, M.; Leguit, R. J.; Weger, R. A.; Huibers, M. M.H., The use of droplet digital PCR in liquid biopsies: A highly sensitive technique for MYD88 p.(L265P) detection in cerebrospinal fluid. Hematological Oncology. 2017, 1-7. https://doi.org/10.1002/hon.2489.

(4) Ye, Q.; Ling, S.; Zheng, S.; Xu, X., Liquid biopsy in hepatocellular carcinoma: circulating tumor cells and circulating tumor DNA. Molecular Cancer, 2019, 18, 114. https://doi.org/10.1186/s12943-019-1043-x.

(5) Wee, E. J. H.; Wang, Y.; Tsao, S. C. H.; Trau, M., Simple, Sensitive and Accurate Multiplex Detection of Clinically Important Melanoma DNA Mutations in Circulating Tumour DNA with SERS Nanotags. Theranostics 2016, 6, 1506-1513. https://doi.org/10.7150/thno.15871.

(6) Zhang, J.; Dong, Y.; Zhu, W.; Xie, D.; Zhao, Y.; Yang, D.; Li, M., Ultrasensitive Detection of Circulating Tumor DNA of Lung Cancer via an Enzymatically Amplified SERS-Based Frequency Shift Assay. ACS Appl. Mater. Interfaces 2019, 11, 18145-18152. https://doi.org/10.1021/acsami.9b02953.

(7) Mao, X.; Pan, S.; Zhou, D.; He, X.; Zhang, Y., Fabrication of DNAzyme-functionalized hydrogel and its application for visible detection of circulating tumor DNA. Sens. Actuators B Chem. 2019, 285, 385-390. https://doi.org/10.1016/j.snb.2019.01.076.

(8) Chen, C.; He, R.; Zhang, Z.; Chen, Y., Dual-recognition-based determination of ctDNA via the clamping function of peptide nucleic acid and terminal protection of small-molecule-linked DNA. Analyst 2020, 145, 7603-7608. https://doi.org/10.1039/D0AN01305F.

(9) Li, D.; Xu, Y.; Fan, L.; Shen, B.; Ding, X.; Yuan, R.; Li, X.; Chen, W., 
Target-driven rolling walker based electrochemical biosensor for ultrasensitive detection of circulating tumor DNA using doxorubicin@tetrahedron-Au tags. Biosens. Bioelectron. 2020, 148, 111826. https://doi.org/10.1016/j.bios.2019.111826.

(10) Cheng, X.; Bao, Y.; Liang, S.; Li, B.; Liu, Y.; Wu, H.; Ma, X.; Chu, Y.; Shao, Y.; $\quad$ Meng, Q.; Zhou, G.; Song, Q.; Zou, B., Flap Endonuclease 1-Assisted DNA Walkers for Sensitively and Specifically Sensing ctDNAs. Anal. Chem. 2021, 93, 9593-9601. https://doi.org/10.1021/acs.analchem.1c01765.

(11) Seferos, D. S.; Prigodich, A. E.; Giljohann, D. A.; Patel, P. C.; Mirkin, C. A. Polyvalent DNA Nanoparticle Conjugates Stabilize Nucleic Acids. Nano Lett. 2009, 9, 308-311. https://doi.org/10.1021/n1802958f.

(12) Li, C.; Luo, S. Wang, J.; Shen, Z.; Wu, Z. S., Nuclease-resistant signaling nanostructures made entirely of DNA oligonucleotides, Nanoscale, 2021, 13, 7034-7051. https://doi.org/10.1039/D1NR00197C.

(13) Brady, R. A.; Brooks, N. J.; Cicuta,P.; Michele, L. D., Crystallization of amphiphilic DNA C-Stars. Nano Lett. 2017, 17, 5, 3276-3281. https://doi.org/10.1021/acs.nanolett.7b00980.

(14) Zheng, J.; Zhu, G.; Li, Y.; Li, C.; You, M.; Chen, T.; Song, E.; Yang, R.; Tan, W., A Spherical Nucleic Acid Platform Based on Self-Assembled DNA Biopolymer for High-Performance Cancer Therapy. ACS Nano 2013, 7, 8, 6545-6554. https://doi.org/10.1021/nn402344v. 